\title{
Re-ensiling translocated triticale silage: To inoculate or not to inoculate ? $^{1,2}$
}

\author{
Luis C. Solórzano ${ }^{3}$, Luis L. Solórzano ${ }^{4}$ and \\ Abner A. Rodríguez-Carias ${ }^{5}$
}

J. Agric. Univ. P.R. 100(2):171-181 (2016)

ABSTRACT

Triticale ( $x$ Triticosecale spp.) silage initially inoculated or not with homolactic bacteria (HBI) was stored in 3 L capacity PVC mini-silos for $120 \mathrm{~d}$. After opening four mini-silos per treatment, silages were mixed and exposed to air (AE) for $5 \mathrm{~h}$. Then half of the non-inoculated silage and half of the inoculated silage were re-treated with a water soluble HBI or water, thus resulting in four combinations of experimental treatments (initial ensiling/re-ensiling): 1) noninoculated/non-inoculated (N/N); 2) non-inoculated/HBI (N/HBI); 3) HBI/noninoculated $(\mathrm{HBI} / \mathrm{N}) ; 4)$ inoculated/inoculated $(\mathrm{HBI} / \mathrm{HBI})$. Silages were re-ensiled for $120 \mathrm{~d}$ at a temperature of 20 to $23^{\circ} \mathrm{C}$ using four vacuum sealed, $0.946 \mathrm{~L}$ capacity glass mini-silos per treatment. Upon opening the mini-silos, silages were sampled and analyzed for nutritional and fermentation characteristics and aerobic stability (AS). Inoculation at the initial ensiling (treatments $\mathrm{HBI} / \mathrm{N}$ and $\mathrm{HBI} / \mathrm{HBI}$ ) was key in preserving the protein fraction and improving fiber digestibility, while decreasing the $\mathrm{pH}$ and contents of fiber fractions, $\mathrm{NH}_{3}-\mathrm{N}$ and ethanol. The resulting silages were all aerobically stable and there were no differences among treatments. The benefits of inoculating at the initial ensiling carried through re-ensiling. Inoculation at re-ensiling was neither beneficial nor detrimental to any of the characteristics evaluated.

Key words: triticale, silage, re-ensiling, bacterial inoculation, fermentation

\section{RESUMEN}

Reensilamiento de ensilaje de triticale trasegado: ¿Se debe inocular o no inocular?

Ensilaje de triticale inoculado o no inicialmente con bacteria homoláctica (IBH) se almacenó en minisilos de PVC de $3 \mathrm{~L}$ de capacidad durante $120 \mathrm{~d}$. Luego de abrir cuatro minisilos por tratamiento, los ensilajes se mezclaron y se expusieron al aire durante $5 \mathrm{~h}$. La mitad del ensilaje sin inocular y la mitad del ensilaje inoculado fueron tratados de nuevo con un IBH hidrosoluble o con la misma cantidad de agua, obteniéndose así cuatro combinaciones de tratamientos experimentales (primer ensilado/reensilado): 1) Sin inocular/ sin inocular (SIN/SIN); 2) sin inocular/IBH (SIN/BH); 3) IBH/Sin inocular (IBH/ $\mathrm{SIN}$ ); 4) inoculado/inoculado (IBHИBH). Los ensilajes se reensilaron por $120 \mathrm{~d}$

${ }^{1}$ Manuscript submitted to the Editorial Board 25 August 2016.

${ }^{2}$ The authors wish to thank Anabel Rodríguez for her assistance in the translation of the manuscript.

${ }^{3}$ Adjunct Professor, Animal Science Department, Univ. of Puerto Rico, Mayagüez

Campus, PO Box 9000, Mayagüez, PR 00680. E-mail: luis.solorzano1@upr.edu.

${ }^{4}$ Independent Researcher, 5839 Devoro Rd., Fitchburg, WI 5371.

${ }^{5}$ Professor, Animal Science Department, Univ. of Puerto Rico, Mayagüez Campus. 


\begin{abstract}
a una temperatura de 20 a $23^{\circ} \mathrm{C}$ utilizando por tratamiento cuatro minisilos de cristal con una capacidad de $0.946 \mathrm{~L}$ y sellados al vacío. Al abrirse los silos, se obtuvieron muestras de los ensilajes que se analizaron para determinar las características nutricionales y fermentativas y la estabilidad aeróbica (EA). La inoculación previa al primer ensilado (tratamientos IBH/SIN e IBHИBH) fue clave en la preservación de la fracción proteica y para mejorar la digestibilidad de la fibra, a la vez que disminuyó el pH y los contenidos de fracciones de fibra, $\mathrm{NH}_{3}-\mathrm{N}$ y etanol. Todos los ensilajes resultantes fueron estables aeróbicamente y no hubo diferencias entre los tratamientos. Los efectos beneficiosos de la inoculación previa al primer ensilaje permanecieron en el reensilado. La inoculación previa al reensilado no representó ni beneficios ni detrimentos en ninguna de las características evaluadas.
\end{abstract}

Palabras clave: triticale, ensilaje, reensilamiento, inoculación bacteriana, fermentación

\title{
INTRODUCTION
}

Silage has become a translocatable commodity as land scarcity increases near dairy farms and crops are grown far away from the location where cattle are kept. Today, it is common practice to ensile crops near the location where they were produced and then transport them to the dairy farm for daily feeding. The principle of ensiling is based on the removal of oxygen from the storage system, the conversion of carbohydrates to organic acids and achieving a low $\mathrm{pH}$. Relocation of silage will deliberately expose fermented forages to oxygen, their worst enemy. Silage may be transported upwards of $100 \mathrm{~km}$ to the farm where it will be used. If the farm is large enough, it may receive and consume daily shipments of fresh silage. Smaller farms ( $<125$ cows) on the other hand, may receive a shipment of silage on a weekly basis. In those farms where shipments are sporadic, some dairy producers pack the silage upon delivery to diminish its aerobic deterioration and heating. Dairy producers often ask whether the silage could be transported in large quantities and re-ensiled at the dairy farm for later use. Also, there may be other situations that lead to a need for re-ensiling at the dairy farm, such as: 1) controlling available forage inventories as a consequence of sales/purchases of forages (Shaver and Leverich, 1999); 2) not having to depend on daily/weekly forage transportation; 3) avoiding the effects of inclement weather during transport and delivery of silage; 4) consolidating silage inventory to make room for new silage (Shaver and Leverich, 1999; Chen and Weinberg, 2014); 5) increasing available time for other tasks during the busy harvest season and consolidating forage inventories during the cooler and less busy time of the year; and 6) allowing for long term storage of high moisture ingredients, e.g. wet brewers grains (Schmelz et al., 2010). Scientific studies on silage re-ensiling are very limited and most of the information available is based on testimonials. 
Inoculation with lactic acid bacteria is a practice used to dominate the fermentation and accelerate the drop in $\mathrm{pH}$ (Muck, 1988), thus preserving forage dry matter (DM) and nutrients resulting in better quality silages. However, Chen and Weinberger (2014) reported that inoculating wheat silage with lactic acid bacteria accelerated the deterioration of silage when exposed to air. The objective of this study was to determine the effect of re-ensiling triticale silage, with or without the use of a homolactic bacterial inoculant (HBI), on nutritional and fermentation characteristics and on the aerobic stability of the resulting silage.

\section{MATERIALS AND METHODS}

Whole plant triticale (x Triticosecale spp.) was chopped to a theoretical length of cut (TLC) of $20 \mathrm{~mm}$ and inoculated or not inoculated at a rate of $1.1 \mathrm{~g} / \mathrm{t}$ with HBI supplying $>9.1 \times 10^{10} \mathrm{CFU} / \mathrm{g}$ of Lactobacillus plantarum, Enterococcus faecium, Lactococcus lactis, Pediococcus pentosaceus and Pediococcus acidilactici. Triticale was fermented for $120 \mathrm{~d}$ at a temperature of 20 to $23^{\circ} \mathrm{C}$ using $3 \mathrm{~L}$ capacity PVC mini-silos fitted with two-way mechanics to vent gas. Mini-silos were filled with about $2 \mathrm{~kg}$ of the wilted crop at about 35\% dry matter (DM) and 5.2\% of soluble carbohydrates (DM basis). After opening the mini-silos, their contents were mixed within each treatment, sampled and the samples frozen at $-18^{\circ} \mathrm{C}$ until analyzed. Silages were aerobically exposed (AE) for approximately $5 \mathrm{~h}$ to simulate relocation and served as the test material for the present study.

The silages to be re-ensiled differed in their fermentation, but not in their nutritional composition (Table 1). As expected, the inoculated silage, compared with the non-inoculated silage, had a greater $(\mathrm{P}<0.05)$ content of lactic acid (5.33 vs. $3.71 \%$ ) and total volatile fatty acids (VFA: 9.19 vs. $8.18 \%)$ and a lower $\mathrm{pH}(4.87$ vs. 5.07$)$.

After the $5 \mathrm{~h}$ aerobic exposure, half of the non-inoculated silage and half of the HBI silage were re-treated with a water soluble inoculant or a similar amount of water, thus resulting in four combinations of experimental treatments (initial ensiling/re-ensiling): 1) Non-inoculated/non-inoculated (N/N), 2) non-inoculated/HBI (N/HBI), 3) HBI/noninoculated (HBI/N), and 4) inoculated/inoculated (HBI/HBI). Silages were re-ensiled for $120 \mathrm{~d}$ at a temperature of 20 to $23^{\circ} \mathrm{C}$ in $0.946 \mathrm{~L}$ capacity glass mini-silos and vacuum sealed using a Food Saver FM2001 (Sunbeam Corp., Boca Raton, FL, USA 33431) 6 . Sixteen mini-silos

\footnotetext{
${ }^{6}$ Company or trade names in this publication are used only to provide specific information. Mention of a company or trade name does not constitute an endorsement by the Agricultural Experiment Station of the University of Puerto Rico, nor is this mention a statement of preference over other equipment or materials.
} 
TABLE 1.-Nutritional and fermentation characteristics of the triticale silage to be reensiled.

\begin{tabular}{lcc}
\hline Nutritional characteristics $^{1}$ & Non-Inoculated & Inoculated \\
\hline DM, \% & 2 & 31.85 \\
CP, \% & 31.33 & 17.14 \\
ADICP, \% & 16.60 & 0.62 \\
EE, \% & 0.68 & 4.03 \\
ADF, \% & 4.01 & 37.61 \\
aNDF, \% & 38.75 & 55.74 \\
Lignin, \% & 56.63 & 2.57 \\
Starch, \% & 3.02 & 0.56 \\
WSC, \% & 0.29 & 0 \\
NFC, \% & 0 & 9.24 \\
Ash, \% & 8.78 & 14.66 \\
Fermentation characteristics & 14.73 & \\
Lactic Acid, \% & & $5.33 \mathrm{a}$ \\
Acetic Acid, \% & $3.71 \mathrm{~b}^{3}$ & 3.56 \\
Propionic Acid, \% & 4.20 & 0.29 \\
Butyric Acid, \% & 0.28 & 0 \\
Total VFA, \% & 0 & $9.19 \mathrm{a}$ \\
Ethanol, \% & $8.18 \mathrm{~b}$ & 0.87 \\
NH $-\mathrm{N}, \%$ CP & 0.98 & 9.92 \\
pH & 11.02 & $4.87 \mathrm{~b}$ \\
\hline
\end{tabular}

\footnotetext{
${ }^{1}$ Dry matter (DM), crude protein (CP), acid detergent insoluble crude protein (ADICP), ether extract (EE), acid detergent fiber ( $A D F$ ), neutral detergent fiber (aNDF), water soluble carbohydrates (WSC), and non-fibrous carbohydrates (NFC)

${ }^{2}$ Fresh basis; all others DM basis

${ }^{3}$ Within a row, means with different letters differ $\mathrm{P}<0.05$

${ }^{4}$ Volatile fatty acids (VFA)
}

(four per treatment) were filled with about $0.3 \mathrm{~kg}$ of the silages with about $32 \% \mathrm{DM}$ and containing no water-soluble carbohydrates. Upon opening, silages were sampled and analyzed at a commercial facility (Rock River Laboratory, Inc. Watertown, WI, NIRS technique) for DM, crude protein (CP), acid detergent fiber (ADF), amylase treated neutral detergent fiber (aNDF), ether extract (EE), ash, acid detergent insoluble crude protein (ADICP), lignin, starch, water soluble carbohydrates (WSC), and non-fibrous carbohydrates (NFC) contents; $30 \mathrm{~h}$ NDF digestion (NDFd), non-degradable NDF after $240 \mathrm{~h}$ (uNDF240) and total tract NDFd (TTNDFD). Additionally, samples were analyzed by wet chemistry for fermentation characteristics ( $\mathrm{pH}$, lactic acid, acetic acid, propionic acid, butyric acid, ethanol, total VFA, and ammonia nitrogen $\left(\mathrm{NH}_{3}-\mathrm{N}\right)$ at the same laboratory. Statistical analysis was performed using the GLM of SAS (SAS Institute, 2004) as a completely randomized design (CRD) for four treatments replicated four times. Bonferroni's Test was used for mean separation. 
Aerobic stability was determined in the resulting silages by monitoring temperature at $6 \mathrm{~h}$ intervals during $7 \mathrm{~d}$ (Honig, 1986). Approximately $100 \mathrm{~g}$ of each silage was loosely placed in Styrofoam containers and exposed to air in thermally insulated chambers. A $12 \mathrm{~cm}$ Taylor thermometer (model 5989) was placed in the middle of each sample. Aerobic stability was defined as the time after opening for silage temperature to reach $3^{\circ} \mathrm{C}$ above ambient. Data were analyzed using the GLM of SAS (SAS Institute, 2004) as a split plot design with a factorial arrangement of four treatments and 29 time points when temperature was recorded using silo as the fixed factor. Bonferroni's Test was used for mean separation.

\section{RESULTS AND DISCUSSION}

The DM content (Table 2) was similar $(\mathrm{P}>0.05)$ in the four silages after re-ensiling (average $30.8 \%$ ) and slightly wetter than the silages before the simulated relocation and consequent re-ensiling (average $31.6 \%$ ). These results are in agreement with those of Chen and Weinberger (2014) for wheat silages exposed to air for a similar time period prior to re-ensiling. Treatment did not affect $(P>0.05)$ the contents of DM, starch, sugar, NFC and ash (Table 2), but HBI/N and HBI/HBI silages had higher $(\mathrm{P}<0.05) \mathrm{CP}$ content and lower $(\mathrm{P}<0.05)$ contents of $\mathrm{ADF}$ and aNDF compared with the silages from treatment combinations N/N and N/HBI. Chen and Weinberg (2014) reported no changes in the NDF content of re-ensiled wheat silages exposed to air up to 48 $\mathrm{h}$ prior to re-ensiling. The present findings indicate that inoculation before the first ensiling, but not at re-ensiling, was fundamental in preserving the protein fraction while decreasing the fibrous fractions. Both the HBI/HBI and HBI/N silages had improved $(\mathrm{P}<0.05)$ contents of $\mathrm{CP}, \mathrm{ADF}$, and NDF compared with the N/N and N/HBI silages. Using HBI at the initial ensiling seems to be adequate to achieve the desired result. By contrast, the use of HBI at re-ensiling did not improve $(P>0.05)$ any of the nutritional characteristics of triticale silage that had not been previously inoculated.

Re-ensiling resulted in triticale silages with lower $(\mathrm{P}<0.05)$ average content of lactic acid (2.18 vs. $5.33 \%$ ) and total VFA (7.55 vs. $9.19 \%$ ) compared with the inoculated silage prior to aerobic exposure and reensiling (Table 3). In contrast, Kawamoto et al. (2011) reported that the concentrations of lactic acid (\% of DM) increased after re-ensiling Italian ryegrass, irrespective of their DM content, from 1.6\% to $4.6 \%$ (Mild wilting) and from $0.4 \%$ to $2.9 \%$ (Heavy wilting), and with a consequent decline in $\mathrm{pH}$. In the present case, re-ensiling resulted in silages with higher $(\mathrm{P}<0.05)$ content of acetic acid $(5.13$ vs. $3.56 \%)$ and $\mathrm{NH}_{3}-\mathrm{N}(12.11$ 
TABLE 2.-Effect of inoculation with homolactic bacteria on nutritional parameters of re-ensiled triticale silage.

\begin{tabular}{|c|c|c|c|c|c|c|c|c|c|}
\hline \multirow[b]{3}{*}{ Item $(\%)^{2}$} & \multicolumn{8}{|c|}{ Treatment combination $^{1}$} & \multirow[b]{3}{*}{$\mathrm{P}<$} \\
\hline & \multicolumn{2}{|c|}{$\mathrm{N} / \mathrm{N}$} & \multicolumn{2}{|c|}{$\mathrm{N} / \mathrm{HBI}$} & \multicolumn{2}{|c|}{$\mathrm{HBI} / \mathrm{N}$} & \multicolumn{2}{|c|}{$\mathrm{HBI} / \mathrm{HBI}$} & \\
\hline & Mean & $\mathrm{SD}$ & Mean & $\mathrm{SD}$ & Mean & $\mathrm{SD}$ & Mean & $\mathrm{SD}$ & \\
\hline $\mathrm{DM}^{3}$ & 31.38 & 1.56 & 29.77 & 0.59 & 31.30 & 0.23 & 30.64 & 0.44 & 0.08 \\
\hline $\mathrm{CP}$ & $15.08 \mathrm{~b}^{4}$ & 0.47 & $15.27 \mathrm{~b}$ & 0.28 & $16.15 \mathrm{a}$ & 0.32 & $16.13 \mathrm{a}$ & 0.43 & 0.003 \\
\hline ADICP & $0.67 \mathrm{ab}$ & 0.04 & $0.70 \mathrm{a}$ & 0.02 & $0.61 \mathrm{~b}$ & 0.01 & $0.66 \mathrm{ab}$ & 0.05 & 0.04 \\
\hline $\mathrm{ADF}$ & $42.47 \mathrm{a}$ & 0.72 & $42.19 \mathrm{a}$ & 0.43 & $40.90 \mathrm{~b}$ & 0.41 & $40.64 \mathrm{~b}$ & 0.43 & 0.001 \\
\hline aNDF & $58.34 \mathrm{a}$ & 0.53 & $57.88 \mathrm{a}$ & 0.31 & $56.95 \mathrm{~b}$ & 0.39 & $56.58 \mathrm{~b}$ & 0.27 & 0.001 \\
\hline Lignin & $3.85 \mathrm{a}$ & 0.12 & $3.91 \mathrm{a}$ & 0.22 & $3.30 \mathrm{~b}$ & 0.22 & $3.59 \mathrm{ab}$ & 0.29 & 0.01 \\
\hline Starch & 0.27 & 0.01 & 0.29 & 0.04 & 0.28 & 0.03 & 0.29 & 0.05 & 0.79 \\
\hline Sugar & 0.27 & 0.01 & 0.26 & 0.01 & 0.26 & 0.01 & 0.27 & 0.01 & 0.86 \\
\hline $\mathrm{NFC}$ & 6.16 & 0.88 & 6.75 & 0.71 & 7.06 & 0.79 & 7.72 & 0.55 & 0.07 \\
\hline Ash & 17.45 & 0.78 & 17.14 & 0.31 & 16.72 & 0.96 & 16.51 & 0.58 & 0.28 \\
\hline
\end{tabular}

${ }^{1}$ The four experimental treatments are (initial ensiling/re-ensiling): 1) Non-inoculated/non-inoculated (N/N); 2) non-inoculated/HBI (N/HBI); 3) HBI/noninoculated (HBI/N); 4) inoculated/inoculated (HBI/HBI)

${ }^{2}$ Dry matter (DM), crude protein (CP), acid detergent insoluble crude protein (ADICP), acid detergent fiber (ADF), neutral detergent fiber (aNDF), and nonfibrous carbohydrates (NFC)

${ }^{3}$ Fresh basis, all others DM basis

${ }^{4}$ Within a row, means with a different letter differ $\mathrm{P}<0.05$ 
TABLE 3.-Effect of inoculation with homolactic bacteria on fermentation parameters of re-ensiled triticale silage (DM basis).

\begin{tabular}{|c|c|c|c|c|c|c|c|c|c|}
\hline \multirow[b]{3}{*}{ Item } & \multicolumn{8}{|c|}{ Treatment combination $^{1}$} & \multirow[b]{3}{*}{$\mathrm{P}<$} \\
\hline & \multicolumn{2}{|c|}{$\mathrm{N} / \mathrm{N}$} & \multicolumn{2}{|c|}{$\mathrm{N} / \mathrm{HBI}$} & \multicolumn{2}{|c|}{$\mathrm{HBI} / \mathrm{N}$} & \multicolumn{2}{|c|}{ HBI/HBI } & \\
\hline & Mean & $\mathrm{SD}$ & Mean & $\mathrm{SD}$ & Mean & SD & Mean & SD & \\
\hline Lactic Acid, \% & 1.88 & 0.07 & 1.67 & 0.16 & 2.43 & 1.46 & 2.72 & 0.37 & 0.23 \\
\hline Acetic Acid, \% & 5.37 & 0.56 & 5.70 & 0.321 & 4.13 & 2.43 & 5.30 & 0.35 & 0.36 \\
\hline Propionic Acid, \% & 0.32 & 0.10 & 0.27 & 0.04 & 0.20 & 0.13 & 0.24 & 0.05 & 0.37 \\
\hline Butyric Acid, \% & 0 & 0 & 0 & 0 & 0 & 0 & 0 & 0 & - \\
\hline Ethanol, \% & 0.99 & 0.22 & 1 & 0.16 & 0.58 & 0.35 & 0.69 & 0.12 & 0.06 \\
\hline Total VFA, \% & 7.56 & 0.71 & 7.63 & 0.44 & 6.76 & 4.02 & 8.26 & 0.75 & 0.79 \\
\hline Ammonia, \% CP & $13.07 \mathrm{ab}^{2}$ & 1.31 & $13.66 \mathrm{a}$ & 0.94 & $11.09 \mathrm{bc}$ & 0.78 & $10.63 \mathrm{c}$ & 1.01 & 0.003 \\
\hline $\mathrm{pH}$ & $5.18 \mathrm{a}$ & 0.03 & $5.23 \mathrm{a}$ & 0.04 & $4.96 \mathrm{~b}$ & 0.04 & $4.94 \mathrm{~b}$ & 0.04 & 0.0001 \\
\hline
\end{tabular}

${ }^{1}$ The four experimental treatments are (initial ensiling/re-ensiling): 1) non-inoculated/non-inoculated (N/N); 2) non-inoculated/HBI (N/HBI); 3) HBI/noninoculated (HBI/N); 4) inoculated/inoculated (HBL/HBI)

${ }^{2}$ Within a row, means with different letters differ $P<0.05$ 
vs. $9.92 \% \mathrm{CP}$ ) and a higher pH (5.08 vs. 4.87$)$ compared with the inoculated silage prior to aerobic exposure and re-ensiling, whereas similar $(\mathrm{P}>0.05)$ content of propionic acid $(0.26$ vs. $0.29 \%)$ and ethanol $(0.82$ vs. $0.87 \%$ ) were observed. Butyric acid was not detectable either before or after re-ensiling, which contrasts with the high levels reported by Chen and Weinberger (2014). Treatment combinations did not affect $(P>0.05)$ the contents of lactic, acetic, propionic and butyric acids nor total VFA (Table 3). However, Chen and Weinberger (2014) failed to find changes in $\mathrm{pH}$, lactic acid, and acetic acid of re-ensiled wheat after up to $48 \mathrm{~h}$ of aerobic exposure. In that study ethanol content did not change significantly in silages that had been exposed to air prior to re-ensiling for a similar period as in the present study. These differences in the results of the two studies may be due to higher moisture content of the wheat silage ensiled by Chen and Weinberger (2014). The HBI/HBI silage treatment resulted in the lowest $\mathrm{NH}_{3}-\mathrm{N}$ content, which was below $(\mathrm{P}<0.05)$ that of the N/N and N/HBI silages, but not the HBI/N silage. The HBI/N silage had a lower $(\mathrm{P}<0.05) \mathrm{NH}_{3}-\mathrm{N}$ compared with the $\mathrm{N} / \mathrm{HBI}$ silage but did not differ from the $\mathrm{N} / \mathrm{N}$ silage. Inoculation before the initial ensiling (HBI/N and HBI/HBI) resulted in lower $(\mathrm{P}<0.05) \mathrm{NH}_{3}-\mathrm{N}(\mathrm{CP}$ equivalent) and $\mathrm{pH}$ compared with the silages that were not so treated (N/N and $\mathrm{N} / \mathrm{HBI}$ ). Inoculation at first ensiling (HBI/N and HBI/HBI) also tended $(\mathrm{P}<0.06)$ to reduce the content of ethanol. Re-inoculation with homolactic bacteria did not affect $(\mathrm{P}>0.05)$ the VFA contents of triticale silages that were re-ensiled. This lack of effect was probably due to the very low content of starch and the absence of WSC in the silages to be re-ensiled (Table 1), which would be expected to inhibit the development of the lactic acid bacteria provided by re-inoculation.

The HBI/N and HBI/HBI silages had higher $(\mathrm{P}<0.05) 30 \mathrm{~h}$ NDF digestibility compared with the silages from the treatments $\mathrm{N} / \mathrm{N}$ and N/HBI (Table 4), which indicates that inoculation at the initial ensiling, but not at re-ensiling, improved fiber digestibility while also decreasing the content of the fibrous fractions (Table 2). The lowest $\mathrm{uNDF} 240(\mathrm{P}<0.05)$ and highest TTNDFD values favored $\mathrm{HBI} / \mathrm{N}$ silage, which differed $(\mathrm{P}<0.05)$ from the N/HBI silage in both characteristics but not from the other two silages. The uNDF240 is a forage fraction that accurately assesses the indigestible component of NDF (Cotanch et al., 2014), while TTNDFD is a direct quantitative predictor of fiber digestion (Combs, 2015). The results of both, uNDF240 and TTNDFD provide support for the beneficial effects of inoculation on fiber digestibility when applied at the initial ensiling. Applying HBI at this time was decisive in improving fiber digestion, whereas the use of HBI at re-ensiling did not improve ( $\mathrm{P}>0.05)$ any of the fiber digestibility characteristics of triticale silage that had not been previously inoculated. 
TABLE 4.-Effect of inoculation with homolactic bacteria (HBI) on neutral detergent fiber (NDF) digestibility of re-ensiled triticale silage.

\begin{tabular}{|c|c|c|c|c|c|c|c|c|c|}
\hline \multirow[b]{3}{*}{ Item $(\% \text { of } \mathrm{NDF})^{2}$} & \multicolumn{8}{|c|}{ Treatment combination ${ }^{1}$} & \multirow[b]{3}{*}{$\mathrm{P}<$} \\
\hline & \multicolumn{2}{|c|}{$\mathrm{N} / \mathrm{N}$} & \multicolumn{2}{|c|}{ N/HBI } & \multicolumn{2}{|c|}{$\mathrm{HBI} / \mathrm{N}$} & \multicolumn{2}{|c|}{ HBI/HBI } & \\
\hline & Mean & $\mathrm{SD}$ & Mean & $\mathrm{SD}$ & Mean & $\mathrm{SD}$ & Mean & $\mathrm{SD}$ & \\
\hline $30 \mathrm{~h}$ NDF digestibility & $44.27 \mathrm{~b}^{3}$ & 1.21 & $43.94 \mathrm{~b}$ & 0.36 & $48.99 \mathrm{a}$ & 0.80 & $47.30 \mathrm{a}$ & 1.03 & 0.0001 \\
\hline uNDF240 & $15.69 \mathrm{ab}$ & 0.29 & $16.00 \mathrm{a}$ & 0.33 & $15.00 \mathrm{~b}$ & 0.19 & $15.60 \mathrm{ab}$ & 0.43 & 0.01 \\
\hline TTNDFD & $40.97 \mathrm{ab}$ & 1.84 & $40.57 \mathrm{~b}$ & 0.54 & $43.64 \mathrm{a}$ & 0.90 & $42.57 \mathrm{ab}$ & 1.30 & 0.015 \\
\hline
\end{tabular}

${ }^{1}$ The four experimental treatments are (initial ensiling/re-ensiling): 1) non-inoculated/non-inoculated (N/N); 2) non-inoculated/HBI (N/HBI); 3) HBI/non-inoculated (HBI/N); 4) inoculated/inoculated (HBI/HBI)

${ }^{2}$ Neutral detergent fiber (NDF), non-degradable NDF after $240 \mathrm{~h}$ (uNDF240) and total tract NDF digestion (TTNDFD)

${ }^{3}$ Within a row, means with different letters differ $\mathrm{P}<0.05$ 
Resulting silages remained stable during the $7 \mathrm{~d}$ of aerobic exposure and no treatment effects $(P>0.05)$ were detected. The average temperature (Figure 1) of the exposed silages during the $7 \mathrm{~d}$ did not differ $(\mathrm{P}>0.05)$ among treatments and remained below ambient temperature $\left(21\right.$ to $\left.23^{\circ} \mathrm{C}\right)$. A significant treatment*hour interaction $(\mathrm{P}<0.05)$ was found, with the HBI/HBI silage showing the most marked hour to hour variation. The present results contrast with those of Chen and Weinberger (2014) in which inoculation with lactic acid bacteria (L. plantarum) exacerbated the aerobic deterioration of re-ensiled wheat silage. The apparent reason for the aerobic stability observed in the present study was the low levels of substrate available to spoilage organisms (starch, WSC and lactic acid) in combination with the inhibitory effect of high levels of acetic acid (5.13\% average) on spoilage organisms.

\section{CONCLUSIONS}

Re-inoculation with HBI at re-ensiling of simulated translocated triticale silage resulted in no important improvements in the nutritional and fermentative characteristics, which was probably due to the lack of starch or water-soluble sugars in the re-ensiled silage. The use of HBI at first ensiling improved CP and fiber levels, and fiber digestion characteristics. The combined use of HBI prior to the initial ensil-

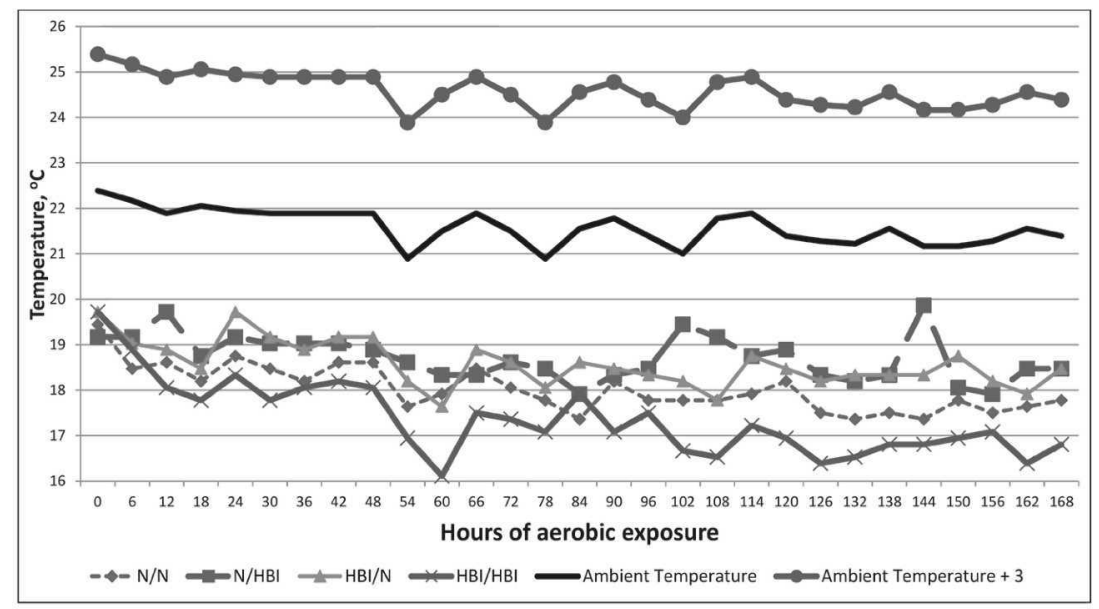

FiguRE 1. Effect of inoculation with homolactic bacteria on silage temperature during the $7 \mathrm{~d}$ aerobic exposure post-opening of re-ensiled whole plant triticale silage. The four experimental treatments are (initial ensiling/re-ensiling): 1) Non-inoculated/noninoculated (N/N); 2) non-inoculated/HBI (N/HBI); 3) HBI/non-inoculated (HBI/N); 4) inoculated/inoculated (HBI/HBI). 
ing and again at re-ensiling tended to result in silage that maintained cooler temperatures during the $7 \mathrm{~d}$ aerobic exposure. The results of this study emphasize the benefits of inoculation of the wilted herbage at first ensiling, which extended to the re-ensiling phase.

\section{LITERATURE CITED}

Chen, Y. and Z. G. Weinberg, 2014. The effect of relocation of whole-crop wheat and corn silages on their quality. J. Dairy Sci. 97: 406-410.

Combs, D., 2015. Forage quality and utilization: Total tract NDF digestibility. In: Proceedings, Western States Alfalfa and Forage Symposium, Reno, NV, 2-4 December, 2015. UC Cooperative Extension, Plant Sciences Department, University of California, Davis, CA 95616.5 pp.

Cotanch, K. W., R. J. Grant, M. E. Van Amburgh, A. Zontini, M. Fustini, A. Palmonari and A. Formigoni, 2014. Applications of UNDF in ration modelling and formulation. Proc. Cornell Nut. Conf. 18 pp.

Honig, H., 1986. Evaluation of aerobic stability. Proc. of the Eurobac Conference, Uppsala, Sweden pp. 76-82.

Kawamoto, H., Y. Satake, J. Zhang, Y. Aoki and M. Kamo, 2011. Effect of shredding and re-ensiling of wrapped round bale on the subsequent silage fermentation. NARO Institute of Livestock and Grassland Science (NILGS) https:/www.naro.affrc.go.jp/ publicity_report/publication/files/naro-se/chiku3-02e.pdf

Muck, R. E., 1988. Factors influencing silage quality and their implications for management. J. Dairy Sci. 71: 2992-3002.

SAS Institute, 2004. SAS/STAT 9.1. User's Guide: SAS Institute, Inc. Cary, NC 275132414, USA.

Schmelz, N. S., M. M. Schutz, T. D. Nennich, R. P. Lemenager, D. Buckmaster and S. S. Donkin, 2010. Effects of re-ensiling corn silage or hay crop silage with wet distillers grains with solubles on aerobic stability of feed mixtures. J. Dairy Sci. 93(5): 2304 (Abstr.).

Shaver, R. and J. Leverich, 1999. Transferring silage between silos. Focus on Forage 1 (7): 2 . 
